\title{
INGESTION OF MICROPLASTICS BY BENTHIC MARINE ORGANISMS IN THE ILHA GRANDE BAY HERITAGE SITE, SOUTHEASTERN BRAZIL
}

INGESTÃO DE MICROPLÁSTICOS POR ORGANISMOS BÊNTICOS MARINHOS NO SITIO DO PATRIMÔNIO DA HUMANIDADE DA ILHA GRANDE, SUDESTE DO BRASIL

\section{Paulo Cezar Azevedo da Silva1, Rayane Sorrentino ${ }^{2 *}$, Brenda dos Santos Ramos ${ }^{3}$, André Rezende de Senna ${ }^{1,2}$, Luis Felipe Skinner ${ }^{1,3}$}

1. Universidade do Estado do Rio de Janeiro (UERJ), Faculdade de Formação de Professores (FFP), Departamento de Ciências (DCIEN). Rua Dr. Francisco Portela, 1470, Patronato, São Gonçalo, RJ, Brasil

2. Universidade Federal Rural do Rio de Janeiro (UFRRJ), Pós-Graduação em Biologia Animal. Rodovia BR 465 - Km7, Seropédica, RJ, Brasil

3. Universidade do Estado do Rio de Janeiro (UERJ), Programa de Pós-graduação em Oceanografia - Brasil

* Corresponding author: rayanesorrentino@gmail.com

ORCID: (iD https://orcid.org/0000-0002-0937-0214

\begin{tabular}{|c|c|}
\hline RECEBIDO EM 08 DE JUNHO DE 2021 & CITAÇÃO: Silva PCA, SORRENTINO R, RAMOS \\
\hline VERSÃO REVISADA EM 03 DE AGOSTO DE 2021 & BS, SENNA AR, SKINNER LF. INGESTION OF \\
\hline ACEITO EM 22 DE AGOSTO DE 2019 & MICROPLASTICS BY BENTHIC MARINE ORGANISMS \\
\hline PUBLICADO EM 27 DE AGOSTO DE 2021 & IN THE ILHA GRANDE BAYHERITAGE SITE, \\
\hline EDITOR RESPONSÁVEL: F. V. ARAÚJO (UERJ) & $\begin{array}{l}\text { SOUTHEASTERN BRAZIL. J. of Human and } \\
\text { Environment of Tropical Bays } 2: 1-13 \text {, } \\
\text { 2021. DOI:10.12957/jheotb.2021.60332 }\end{array}$ \\
\hline
\end{tabular}

\section{Resumo}

O descarte, o manejo e o tratamento inadequado do lixo são os principais motivos do acúmulo de plástico no ambiente. Pessoas, animais, vento, tempestades e correntes marinhas espalham continuamente $o$ plástico em diferentes locais do mundo. Diversos grupos de animais têm ingerido e bioacumulado pequenas partículas de plástico, os microplásticos (MPs). Essa ingestão resulta em diversos efeitos negativos no organismo, como diminuição de taxas nutricionais. O objetivo desse trabalho foi utilizar dois grupos bentônicos para averiguar a presença de microplástico na biota marinha da Baía da Ilha Grande (BIG). Relatamos a ingestão de MP por Ascidiacea e Amphipoda, em diferentes localidades, inclusive em áreas consideradas mais preservadas como Dois Rios e em áreas de proteção ambiental como Piraquara de Fora. Esses dados refletem a necessidade de mais monitoramentos e estudos sobre os efeitos da ingestão de MPs na biota marinha da área, assim como alerta para novos perigos à biodiversidade na região, sendo este o primeiro estudo que identificou a presença de MPs em organismos da BIG.

Palavras-chave: Lixo, contaminação por plástico, área de proteção ambiental, Sudoeste do Atlântico. 


\begin{abstract}
Inappropriate disposal, management, and treatment of litter are the main sources of plastic accumulation in the environment. People, animals, wind, storms, and ocean currents spread continuously the plastic in different sites of the world. Diverse animal groups have been ingesting and bioaccumulating small particles of plastic, the microplastics (MPs). This ingestion results in several negative effects on the body, such as a decrease in nutritional rates. The objective of this work was to investigate the presence of microplastics in marine biota from Ilha Grande Bay (IGB). We report the uptake of MP by Ascidiacea and Amphipoda collected in different sites around BIG. The sites included preserved areas such as Dois Rios and protected areas such as Piraquara de Fora. These data reflect the necessity for more monitoring programs and studies, and warning of new dangers to the biodiversity from the area. This is the first study identifying the presence of MP in organisms from BIG.
\end{abstract}

Keywords: Litter, plastic contamination, environmental protected area, southwest Atlantic.

\title{
Introduction
}

The marine environment accumulates thousands of plastic debris. The lack of proper management of solid waste and the intense human activity on the beaches generate the extreme accumulation of debris in the environment (Silva et al., 2016). Microplastics (MPs) are particularly omnipresent in the marine environment due its diverse sources of origin. They are generated from marine, terrestrial, and atmospheric areas such as coastal sewage, fishing and shipping activities, car tires, textile products (Barnes et al., 2009; Browne et al., 2010; Bucci et al., 2020). Besides that, they are easily transported to long distances by wind, oceanic gyres, and deep ocean currents (Petersen et al., 2016). Shores with intense tourism and large coastal populations have higher levels of plastics and chemical pollutants (McCormick et al., 2016). Animals from these areas accidentally ingest MPs or identified those with incrusted biofilms as food (Oberbeckmann, et al., 2015; Bancone et al., 2020). This contamination results in physiological impact, as entrapment and hormonal changes (Bucci et al., 2020). Several researchers about microplastics are carried out in Brazil (Castro et al., 2018). MPs particles have already been recorded in areas in Rio de Janeiro, mainly in polluted regions, such as Guanabara Bay (Carvalho and Baptista, 2016; Silva et al., 2019), and in the inner shelf of the State of Rio de Janeiro (Baptista et al., 2019). However, it was also recorded in remote areas such as Ilha da Trindade, which is $1,200 \mathrm{~km}$ offshore the coast (Petersen et al., 2016), and in protected areas such as Ilha Grande Bay (IGB) (Macedo et al., 2019). Most of these studies are focused on MPs in environment. This bay possesses many Protected Areas and is recognized for its high ecological importance (MMA 2002). Despite the 
numerous records of invasive animals and an enormous number of marinas and ports, this Bay possesses well-preserved ecosystems and high marine species endemism (Skinner et al., 2016). By this animal diversity, richness and abundance, IGB has 11 conservation units (Creed et al., 2007). One of these areas is the Tamoios Environmental protected area, which was established in 1986. It includes the biggest marine area with integral protection (8,700 hectares) covering islands, slabs, and rocky shore within a $1 \mathrm{~km}$ of radius (INEA, 2020). However, the increasing of demography and tourist activities, and the deficiency of effective implementation of waste management (da Costa and Lima, 2019), tend to increase the accumulation of litter. Although there are monitoring studies of plastic contamination in IGB (Macedo et al., 2017), association with organisms has been not explored.

It is suggested that seabed is a sink for MPs and benthic organisms and filters feeders are frequently exposed to MPs contamination (Cole et al., 2011; Wright et al., 2013). Hence, in this work, the ingestion of MP was analyzed in individuals of two benthic groups that are well distributed in the area, Ascidiacea and Amphipoda. This is the first report of MP ingestion by marine organisms in the Ilha Grande Bay.

\section{Material and methods}

Study site

Ilha Grande Bay includes the municipalities of Mangaratiba, Angra dos Reis and Paraty, in the western region of Rio de Janeiro state in Brazil, and it is defined as a protected area, according to the State constitution (INEA, 2020). The main island has $193 \mathrm{~km}^{2}$ in area, belongs to the southern escarpment of Serra do Mar and has coves, rock shores, beaches, mangroves, and streams. It includes 113 different beaches, some of them face the continent and are more sheltered from waves, and others are exposed to open sea and receive more impact from waves and oceanic currents (Godoi et al., 2011; Gralato, 2016).

Sampling of Ascidiacea and microplastic survey:

In 2018, from six sites along Ilha Grande Bay (Figure 1) sixty individuals (10 individuals from each site) of Phallusia nigra Savigny, 1816 (Figure 2a) were manually collected from natural and artificial substrates by free diving in shallow waters (up to $5 \mathrm{~m}$ deep). Clean plastic bags were used to cover and withdraw the specimens from the substrates. After removing, the individuals were anaesthetized with menthol 
diluted in seawater and then fixed in individual pots with $10 \%$ formaldehyde (this method does not have the potential to affect plastic particles as studied by CourteneJones et al. (2017)). The material was transported to the laboratory at Universidade do Estado do Rio de Janeiro (UERJ) and the animals were dissected to remove the digestive tract (stomach and intestine), and then they were kept in individual containers with $70 \%$ ethanol. The animals' stomachs and all equipment used were externally cleaned with distilled water to avoid external MPs, then they were pooled together according to their location to optimize the analysis (10 individuals per site). The samples were then macerated and immersed in a hypersaline solution ( $358.9 \mathrm{~g}$ of $\mathrm{NaCl}$ in $1 \mathrm{~L}$ of distilled water) for 24 hours to suspend all MP particles. The samples were filtered with vacuum pump Prismatec 121, through $5 \mu \mathrm{m}$ mesh filters (Whatman AE98, cellulose nitrate). The paper filters were placed in Petri dishes to prevent external contamination and to analyze under a stereomicroscope. After drying the paper filters at room temperature, MP was quantified, measured, classified (fiber or fragment) (Syakti et al., 2018) and photographed using a camera (EUREKAM $5.0 \mathrm{mp}$ ) coupled with a stereoscope microscope (Bel Photonics, STEREO-ZOOM SERIE SZ/SZT $(5.6 x)$. During the experiments, behavioral measures were also considered, such as wearing cotton lab coats, keeping the laboratory with fewer people, turning off the air conditioning, and keeping a Petri dish with distilled water to control microplastic area contamination. Microplastics found in the control and similar to those found in the samples were discarded from data.

Sampling of Amphipoda and microplastic survey:

Amphipods collection was performed in August 2019, in the oceanic side, at Jorge Grego Island, Lopes Mendes and in September 2019 in Dois Rios Beach (Figure 1). In Jorge Grego and Lopes Mendes, algae were collected on the rocky shore to access the associated amphipods (Figure $2 \mathrm{~b}$ ). It was manually sampled, covering the tuff of algae with a cleaned plastic bag, with SCUBA and free diving. The material was fixed in ethanol $70 \%$ and taken to the lab. Amphipods have a small body size making hard the dissection of digestive tract. Hence, to access the ingestion of microplastic in amphipods, the body tissue was degraded with acid nitric $100 \%\left(\mathrm{HNO}_{3}\right)$. To avoid external contamination and to observe only the ingested plastic, each sample was washed with distilled water and analyzed in the microscope, then added in a Becker $20 \mathrm{~mL}$ with $5 \mathrm{~mL}$ of $\mathrm{HNO}_{3}$ for $30 \mathrm{~min}$ at $60{ }^{\circ} \mathrm{C}$ (Desforges et al., 2015) in a fume hood to control contamination. After it, each sample was added in a Becker with distillate water and filtered as mentioned above. The microplastic were also measured and 
classified as fragment or fiber. To avoid external contamination, the samples were washed externally with distilled water, as well as the equipment (tweezers, scissors) used during the process and a Petri dish with distilled water was displayed to air control.

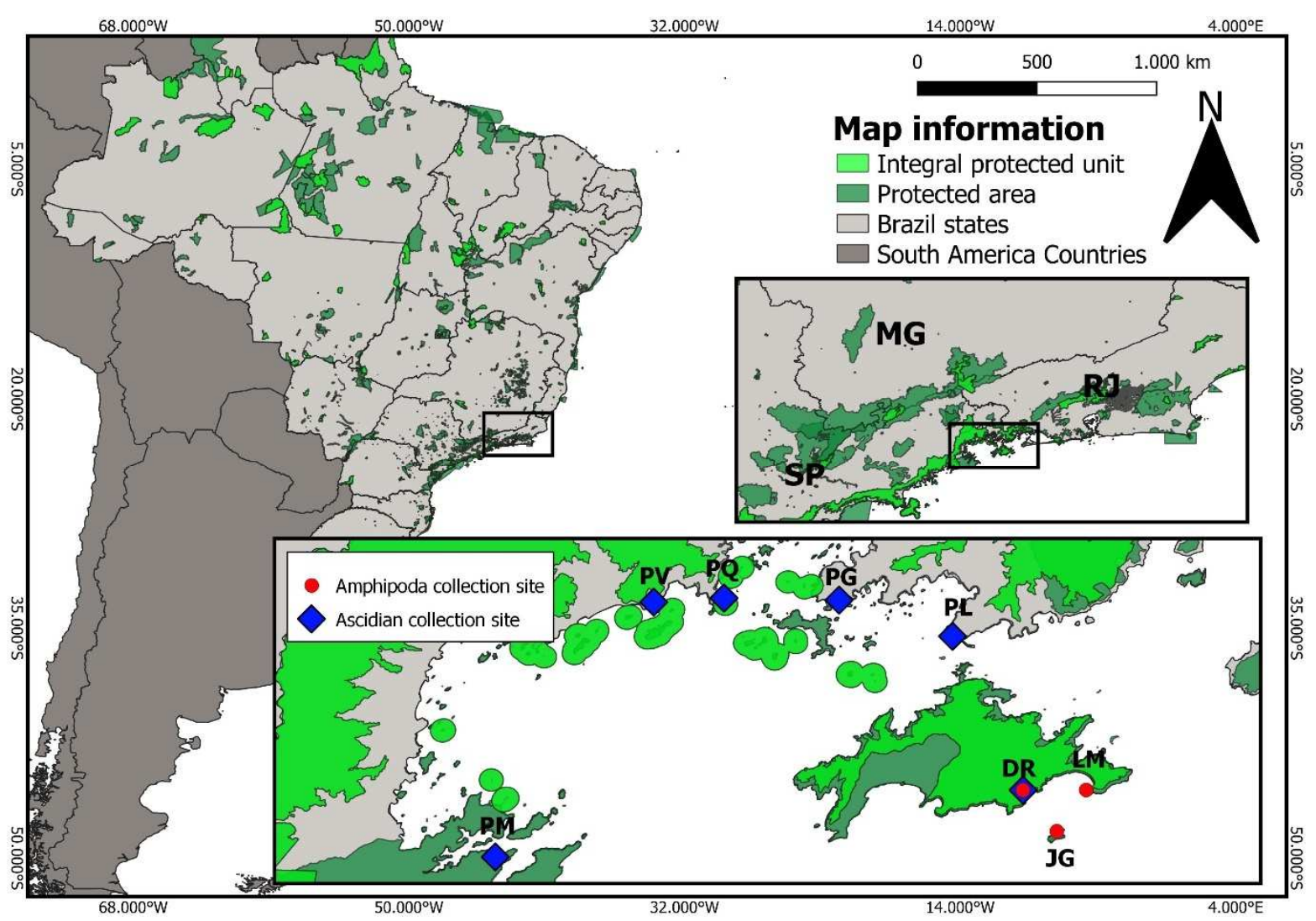

Figure 1: Sampling sites of Ascidiacea and Amphipoda in Ilha Grande Bay. Ponta Leste

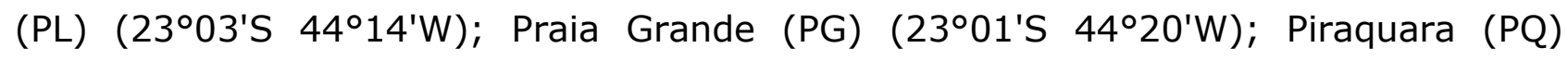

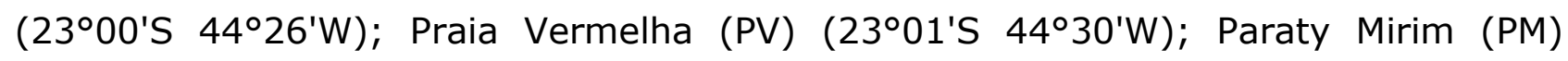

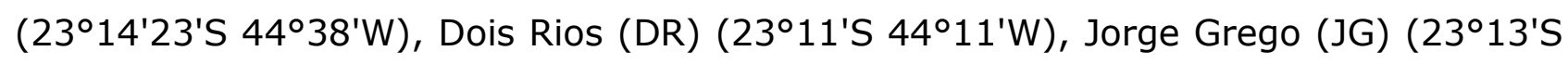

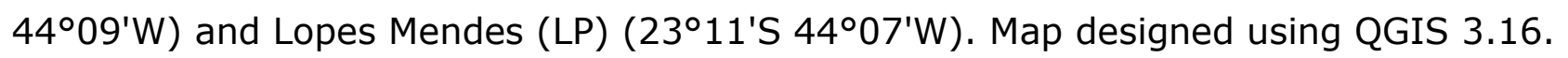

\section{Results}

The presence of MP in the digestive tract of $P$. nigra was detected in four of the six studied sites (excepted for Praia Grande and Paraty Mirim) (Table 1). The number of MP particles on samples from 10 pooled individuals ranged from zero to three (Table 1). 
Table 1: Number and size (maximum and minimum length in $\mathrm{mm}$ ) of microplastics fragments (frag.) and fiber found in the digestive tract (mean length and width in $\mathrm{cm}$ ) of Phallusia nigra during survey among sites at Ilha Grande Bay.

\begin{tabular}{ccccc}
\hline Locality & MP No & $\begin{array}{c}\text { Frag. } \\
\mathbf{( m m )}\end{array}$ & $\begin{array}{c}\text { Fiber } \\
\mathbf{( m m )}\end{array}$ & $\begin{array}{c}\text { Intestine mean size } \\
\text { (length and width) }\end{array}$ \\
\hline $\begin{array}{c}\text { Ponta Leste } \\
\text { Praia Vermelha }\end{array}$ & 3 & 0.4 & $0.6-2.7$ & $2.8 \mathrm{~cm} \times 1.6 \mathrm{~cm}$ \\
Praia Grande & 0 & -- & $0.5-1.4$ & $1.7 \mathrm{~cm} \times 1.2 \mathrm{~cm}$ \\
Piraquara & 2 & -- & -- & $2.9 \mathrm{~cm} \times 1.8 \mathrm{~cm}$ \\
Paraty Mirim & 0 & -- & 2.3 & $2.7 \mathrm{~cm} \times 1.7 \mathrm{~cm}$ \\
Dois Rios & 2 & 0.7 & 1.06 & $2.5 \mathrm{~cm} \times 1.7 \mathrm{~cm}$ \\
\hline
\end{tabular}

Surveys for Amphipods in Jorge Grego and Lopes Mendes resulted in 80 individuals containing five fragments. At Dois Rios, it was recorded 134 individuals having four fragments and five microfibers.

Table 2: Number and size (maximum and minimum length in $\mathrm{mm}$ ) of microplastics fragments (frag.) and fiber found within amphipods from Jorge Grego, Lopes Mendes and Dois Rios, Ilha Grande Bay, Rio de Janeiro state, Brazil.

\begin{tabular}{ccccc}
\hline Site & Ind. & MP No & $\begin{array}{c}\text { Frag. } \\
\mathbf{( m m})\end{array}$ & $\begin{array}{c}\text { Fiber } \\
(\mathbf{m m})\end{array}$ \\
\hline $\begin{array}{c}\text { Jorge Grego/Lopes Mendes } \\
\text { Dois Rios }\end{array}$ & 80 & 5 & $0.08-0.7$ & -- \\
134 & 9 & $0.1-1.1$ & $0.07-0.8$ \\
\hline
\end{tabular}

\section{Discussion}

Even with a high sampling effort, we had low representativeness of Amphipoda around the area. This sampling was made after a period of strong waves and high tides, which compromised the collection of algae to access the amphipod specimens. Nevertheless, for the first time, the presence of microplastic on benthic animals at Ilha Grande Bay was investigated. Beyond the tourist importance and the presence of several conservation units in the region, Ilha Grande Bay has several shell farms (Angra dos Reis, 2021a, b). As microplastic contamination has been reported in a range of commercial marine animals (Barbosa et al., 2018), especially mollusks (Dela-Torre et al., 2019), it may be a threat to this seafood commerce and to the local population. In monitoring studies in beaches of Ilha Grande, plastic was the most representative waste from all beaches, including that one exposed to open ocean, with 
small villages or closer to the continent (Macedo et al., 2017; Madureira et al., 2017). This is the first evidence of microplastic presence in Lopes Mendes, which was not registered by Macedo et al., (2019). Regarding ingestion of microplastic, beaches closer to shipping and touristic activities (Ponta Leste and Dois Rios) have ascidians and amphipods with more MP. Praia Vermelha beach, beyond its easy access, has low parking facilities and beach waves break in high energy, reducing the number of tourists and anchored boats. On this site, close to the resident village of Eletronuclear and from Mambucaba estuary, ascidians had more MP ingested. Both proximities can contribute as a source of MPs.

Domestic clothing washes are among the main sources of plastic fibers contamination in marine environment (Wright et al., 2015; Carr et al., 2016; Cole et al., 2016), but degradation of fishing gear, such as ropes, and nets can increase the amount of those particles in water. Ilha Grande Bay houses the highest concentration of recreational boats and marinas in Latin America (Skinner et al., 2016). It also has intense fishing and aquaculture activities. Fishing gear is one of the most frequent types of litter found in sand beaches in this region (Madureira et al., 2017; Macedo et al., 2017, 2020). Despite the low concentration of ingested microplastics, our results support that both, benthic ascidians and amphipods, are ingesting microfragments and microfibers in natural contexts. Prior surveys already show some negative effects of microplastic contamination in ascidians and amphipods. Laboratory experiments with species of Ciona intestinalis (Linnaeus, 1767) and C. robusta Hoshino \& Tokioka, 1967 show that accumulation of MP in organisms can lead to deformation of individuals, delay of metamorphosis, and nutritional impairment that affects the growth of ascidians (Messinett et al., 2019; Vered et al., 2019). In amphipods negative effects on animal feeding behavior, influencing its growth and ecological function, have already been observed (Carrasco et al., 2019; Jamieson et al., 2019). Also, it shows that even in a conserved area, microplastics are present by many different factors. The analyzes can contribute to future conservation actions and the management of marine resources. 
Study limitations

It is important to highlight that this study had few limitations as the low density of amphipods. Notwithstanding, this is a baseline for future studies around the area, which may include other assemblages of organisms and report the consequences of microplastic pollution in this conservation area.
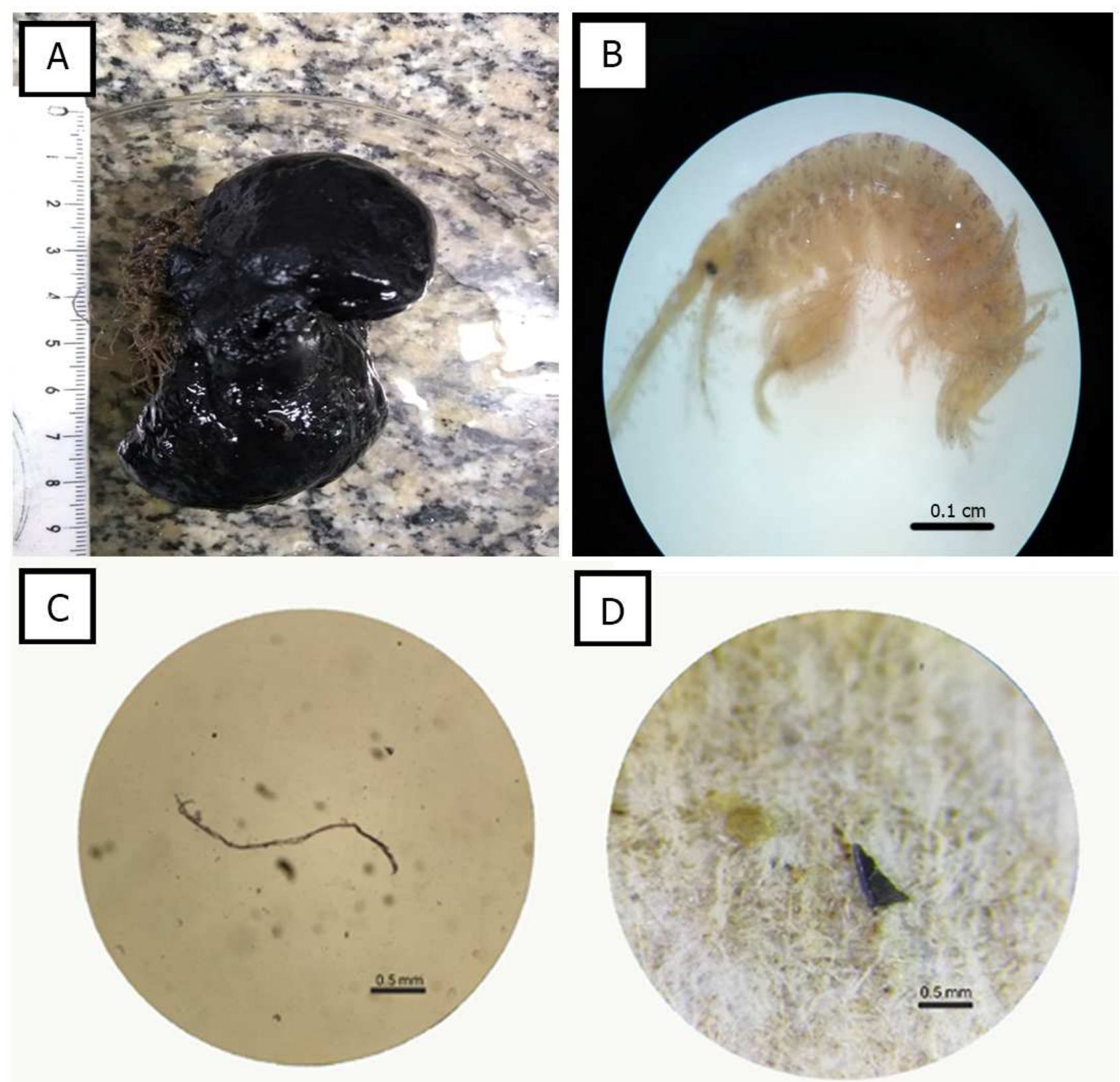

Figure 2: Illustrative images of the species. (a) The Ascidiacea Phallusia nigra; (b) The Amphipoda: Ampithoidae Cymadusa sp.; Photos of microplastics found inside the amphipods and the digestive system of the ascidia Phallusia nigra. (c) Microplastic Microfiber; (d) Microplastic - Fragment. 


\section{Acknowledgements}

This work was financed in part by the Programa de Treinamento e Capacitação Técnica (FAPERJ No 04/2019) for P.C.A.S; Coordenação de Aperfeiçoamento de Pessoal de Nível Superior - Brazil (CAPES) - Finance Code 001, regarding the Ph.D thesis of R.S and B.S.R; A.R.S and L.F.S are supported by Programa de Incentivo à Produção Científica, Técnica e Artística (PROCIÊNCIA); ARS also supported by Fundação Carlos Chagas Filho de Amparo à Pesquisa do Estado do Rio de Janeiro (FAPERJ), process number E-26/202.768/2019. We are thankful for CEADS UERJ and ESEC Tamoios for the Logistical support during fieldworks. Surveys are performed under licences from INEA and SISBIO (Auth. \#057/2011, 025/2017 and 029/2019) and Estação Ecológica Tamoios (ICMBio - Auth. \#36194).

\section{Conflict of interest statement}

On behalf of all authors, the corresponding author states that there is no conflict of interest.

Paulo Cezar Azevedo da Silva; (iD) https://orcid.org/0000-0002-6896-8363

Rayane Sorrentino; (iD https://orcid.org/0000-0002-0937-0214

Brenda dos Santos Ramos; (iD https://orcid.org/0000-0001-5710-1097

André Rezende de Senna; (Dhttps://orcid.org/0000-0003-0976-849X

Luis Felipe Skinner; (D) https://orcid.org/0000-0003-0971-4870

\section{References}

Angra dos Reis, Secretaria de Pesca (2021a). Produção da Maricultura https://www.angra.rj.gov.br/spe-

estatistica-

maricultura. asp? IndexSigla $=$ SEAAP $\& v N$ No meLink $=$ Produ $\% E 7 \% E 30 \% 20-$

\%20Maricultura. Acesso em 07/06/2021

Angra dos Reis, Secretaria de Pesca (2021b). Mapa de Distribuição das Áreas de Cultivo na Baía da Ilha Grande.

https://www.angra.rj.gov.br/spemapadedistribuicao.asp? IndexSigla $=\mathrm{SE}$
AAP\&vNomeLink=Mapa\%20de\%20Distri bui\%E7\%E30

AU, S. Y.; LEE, C.M.; WEINSTEIN, J. E.; HURK, P.; KLAINE, S. J. 2017. Trophic transfer of microplastics in aquatic ecosystems: Identifying critical research needs. Integr. Environ Assess Manag. 13 (3): 505-509.

https://doi.org/10.1002/ieam.1907 
BANCONE, C. E. P.; TURNER, S. D.; IVAR DO SUL, J. A.; ROSE, N. L. The Paleoecology of Microplastic Contamination. 2020. Front. Environ. Sci. 8:574008.

https://doi.org/10.3389/fenvs.2020.574008

BAPTISTA NETO, J. A.; DE CARVALHO, D. G.; MEDEIROS, K.; DRABINSKI, T. L.; DE MELO, G. V.; SILVA, R. C. O.; SILVA, D. C. P; DE SOUSA BARBOZA, L. G. A.; VETHAAK, A. D.; LAVORANTE, B. R. B. O.; LUNDEBYE, A; GUILHERMINO, L. 2018. Marine microplastic debris: An emerging issue for food security, food safety and human health. Mar Pollut Bull 133: 336-348. https://doi.org/10.1016/j.marpolbul.2018.05. $\underline{047}$

BARNES, D. K. A.; GALGANI, F.; THOMPSON, R. C.; BARLAZ, M. 2009. Accumulation and fragmentation of plastic debris in global environments.

Philos Trans R Soc 364:1985-1998. https://doi.org/10.1098/rstb.2008.0205

BATISTA, L.; DIAS, G. T. M.; DA FONSECA, E. M.; DOS SANTOS FILHO, J. R. 2019. The impact of sediment dumping sites on the concentrations of microplastic in the inner continental shelf of Rio de Janeiro/Brazil. Mar Pollut Bull. 149:110558, https://doi.org/10.1016/i.marpolbul.2019.11 $\underline{0558}$
BROWNE, M. A.; GALLOWAY, T. S.; THOMPSON, R. C. 2010. Spatial patterns of plastic debris along estuarine shorelines. Environ Sci Technol 44: 3404-3409. https://doi.org/10.1021/es903784e

BUCCI, K., TULIO, M. ROCHMAN, C. M. 2020. What is known and unknown about the effects of plastic pollution: $A$ meta-analysis and systematic review. $\begin{array}{llll}\text { Ecol Appl } 30 & \text { (2):e02044. }\end{array}$ https://esajournals.onlinelibrary.wiley.c om/doi/abs/10.1002/eap.2044

CARR, S. A.; LIU J, TESORO, A. G. 2016. Transport and fate of microplastic particles in wastewater treatment plants. Water Res 91: 174-182, https://doi.org/10.1016/j.watres.2016.0 $\underline{1.002}$

CARRASCO, A.; PULGAR, J.; QUINTANILHA-AHUMADA， D.; PEREZVENEGAS, D.; QUIJÓN, P. A.; DUARTE, C. 2019. The influence of microplastics pollution on the feeding behavior of a prominent sandy beach amphipod, Orchestoidea tuberculata (Nicolet, 1849). Mar Pollut Bull, 145: 23-27. https://doi.org/10.1016/j.marpolbul.2019.05. $\underline{018}$

CARVALHO, D. G.; BAPTISTA-NETO, J. A. 2016. Microplastic pollution of the beaches of Guanabara Bay, Southeast Brazil. Ocean Coast Manag 128:1017.

https://doi.org/10.1016/j.ocecoaman.2016.0 4.009 
Silva et al., JHEOTB 2:1-13, 2021

CASTRO, R. O.; SILVA, M. L.; ARAÚJO, F. V. 2018. Review on microplastic studies in Brazilian aquatic ecosystems.

Ocean Coast Manag.165: 385-400. https://doi.org/10.1016/j.ocecoaman.2 $\underline{018.09 .013}$.

COLE, M.; LINDEQUE, P.K.; FILEMAN, E.; CLARK, J.; LEWIS, C.; HALSBAND, C.; GALLOWAY, T. S. 2016. Microplastics alter the properties and sinking rates of zooplankton faecal pellets. Environ Sci Technol 50: 3239-3246.

http://dx.doi.org/10.1021/acs.est. 5b05905.

COURTENE-JONES， W; QUINN， B.; MURPHY, F.; GARYA, S. F.; NARAYANASWAMYA， B. E. 2017. Optimisation of enzymatic digestion and validation of specimen preservation methods for the analysis of ingested microplastics. Anal. Methods, 9: 14371445. https://doi.org/10.1039/C6AY02343F

CREED, J.C.; ABSALÃO, R.S.; BRASIL, A. C.S.; FIGUEIREDO, M. A. O.; FERREIRA， C. E.L.; PIRES D. O.; SEREJO, C. S.; VENTURA, C. R. R. 2007. Sumário Executivo. In: Biodiversidade Marinha da Baía da Ilha Grande. Série Biodiversidade 23. Creed, J.C.; Pires, D.O.P.; Figueiredo, M.A.O. (orgs). MMA, Brasília.
DA COSTA, A. J. S. T.; LIMA, C. S. 2019. Recicla ilha: uma proposta de gestão para os resíduos sólidos urbanos em Ilha Grande/RJ. XIII ENANOPEGE. https://www.enanpege2019.anpege.ggf .br/resources/anais/8/1560558070 ARQ UIVO trabalhocompletocongresso.pdf Acesso em 14 de abril de 2020

DE-LA-TORRE， G. E.; MENDOZACASTILLA, L.; LAURA, R. P. 2019. Microplastic contamination in market bivalve Argopecten purpuratus from Lima, Peru. Manglar, 16 (2): 85-89.

DESFORGES， J. W.; GALBRAITH， M.; ROSS, P. S. 2015. Ingestion of Microplastics by Zooplankton in the Northeast Pacific Ocean. Arch Environ Contam Toxicol 69:320-330. DOI 10.1007/s00244-015-0172-5

GODOI, V. A.; CALADO, L.; WATANABE, W. B.; YAGINUMA, L. E.; BASTOS, M. 2011. Evento extremo de ondas na Baía da Ilha Grande: um estudo de caso. BOAARL 5(2):27-44.

GRALATO, J. C. A. 2016. Dinâmica costeira e vulnerabilidade do litoral oriental da Ilha Grande (Angra dos Reis - RJ) às ondas de tempestades. Dissertation, Universidade do Estado do Rio de Janeiro.

HOSHINO, Z.; TOKIOKA, T. 1967. An unusually robust Ciona from the northeastern coast of Honsyu Island, Japan. Publ. Seto Mar. Biol. Lab. 15(4): 275-290. 
INEA Instituto Estadual do Ambiente http://www.inea.ri.gov.br/biodiversidad e-territorio/conheca-as-unidades-deconservacao/apa-de-tamoios/ Acesso em 12 de abril de 2020

JAMEISON, A. J.; BROOKS, L. S. R.; REID, W. D. K.; PIERTNEY, S. B.; NARAYANASWAMY, B. E.; LINLEY, T. D. 2019. Microplastics and synthetic particles ingested by deep-sea amphipods in six of the deepest marine ecosystems on Earth. Royal Society Open Science, 6(2), 180667. https://doi.org/10.1098/rsos.180667

LINNAEUS, C. (1767). Systema naturae per regna tria naturae: secundum classes, ordines, genera, species, cum characteribus, differentiis, synonymis, locis. Ed. 12. 1., Regnum Animale. 1 \& 2. Holmiae [Stockholm], Laurentii Salvii. pp. 1-532 [1766] pp. 533-1327 [1767].https://www.biodiversitylibrary.org/i $\underline{\text { tem } / 83650}$

MACEDO, A. V.; SILVA, A. L. C.; MADUREIRA, E. A. L. 2019. Ocorrência e distribuição de microplásticos no litoral da Ilha Grande (Angra dos Reis, RJ). In:

Geografia Física $e$ as Mudanças Globais Edições: UFC. 12pp

MACEDO, A. V.; SILVA, A. L. C.; MADUREIRA, E. A. L.; DINIZ, L. F.; PINHEIRO, A. B. 2020. Poluição por resíduos sólidos em praias da Baía da Ilha Grande: Angra dos Reis e Paraty (RJ). Mares: revista de Geografia e Etnociências, 1: 53-66.
MACEDO, A. V.; SILVA, A. L. C.; MADUREIRA, E. A. L.; SILVESTRE, C. P. 2017. Poluição por lixo nas praias de Abraão e Preta na borda setentrionaloriental da Ilha Grande (Angra dos Reis, RJ) e o impacto socio-ambiental. In: Perez Filho A, Amorin RR (org). Os desafios da geografia física na fronteira do conhecimento. Campinas, pp 3009-3014.

MADUREIRA, E. A. L.; DA SILVA, A. L. C.; MACEDO, A. V.; GRALATO, J. C. 2017. A. Análise da composição, distribuição e origem do lixo nas praias oceânicas de Dois Rios e Lopes Mendes na Ilha Grande (Angra dos Reis, RJ). In: Perez Filho A, Amorin RR (org). Os desafios da geografia física na fronteira do conhecimento.

Campinas, pp 3015-3020.

MCCORMICK, A. R.; HOELLEIN, T. J.; LONDRES, M. G.; HITTIE, J.; SCOTT, J. W.; KELLY, J. J. 2016. Microplastic in surface waters of urban rivers: concentration, sources, and associated bacterial assemblages. Ecosfera 7 (11), e01556.

\section{https://doi.org/10.1002/ecs2.1556}

MMA. 2002. Biodiversidade brasileira avaliação e identificação de áreas e ações prioritárias para a conservação, utilização sustentável e repartição de benefícios da biodiversidade nos biomas brasileiros. Brasília: MMADF. 
OBERBECKMANN, S.; LODER, M. G. J.; LABRENZ, M. 2015. Marine microplasticassociated biofilms - a review. Environ Chem.12(5):551-562.

http://dx.doi.org/10.1071/EN15069

PETERSEN, E. S.; KRÜGER, L.; DEZEVIESKI， A.; PETRY, M. V.; MONTONE, R. C. 2016. Incidence of plastic debris in Sooty Tern nests: A preliminary study on Trindade Island, a remote area of Brazil. Mar Pollut Bull 105:373-376.

http://dx.doi.org/10.1016/j.marpolbul.2 $\underline{016.02 .036}$

SILVA, M. L.; SALES, A. S.; MARTINS, S.; CASTRO, R. O.; ARAÚJO, F. V. 2016. The influence of the intensity of use, rainfall and location in the amount of marine debris in four beaches in Niteroi, Brazil: Sossego, Camboinhas, Charitas and Flechas. Mar Pollut Bull 113:3639.

http://dx.doi.org/10.1016/j.marpolbul.2 $\underline{016.10 .061}$

SKINNER， L. F.; BARBOZA， D. F.; ROCHA, R. M. 2016. Rapid assessment Survey of introduced ascidians in a region with many marinas in the Southwest Atlantic Ocean, Brazil. Manag Biol Invas 7:(1) 13-20. http://dx.doi.org/10.3391/mbi.2016.7.1 .03
SYAKTI, A. D.; HIDAYATI, N. V.; JAYA, Y. V.; SIREGAR, S. H.; YUDE, R.; SUHENDY; ASIA, L.; WONG-WAHCHUNG, P.; DOUMENQ, P. 2018. Simultaneous grading of microplastic size sampling in the Small Islands of Bintan water, Indonesia. Mar Pollut Bull.137:593-600.

https://doi.org/10.1016/j.marpolbul.20 $\underline{18.11 .005}$

TSANG, Y. Y.; MAK, C. W.; LIEBICH C.; LAM, S.W.; SZE, E. T.; CHAN, K.M. 2017. Microplastic pollution in the marine waters and sediments of Hong Kong. Mar Pollut Bull 115: 20-28. https://doi.org/10.1016/j.marpolbul.2016.11. $\underline{003}$

VERED, G.; KAPLAN, A.; AVISAR, D.; SHENKAR, N. 2019. Using solitary ascidians to assess microplastic and phthalate plasticizers pollution among marine biota: A case study of the Eastern Mediterranean and Red Sea. Mar Pollut Bull, 138, 618-625. https://doi.org/10.1016/i.marpolbul.2018.12. $\underline{013}$

WRIGHT, S. L.; THOMPSON, R. C.; GALLOWAY, T.S. 2013. The physical impacts of microplastics on marine organisms: a review. Environ Pollut 178:483-492.

https://doi.org/10.1016/j.envpol.2013.0 $\underline{2.031}$ 